\title{
New species of Enterographa and Fulvophyton from Malaysia and Mexico
}

\author{
Laurens B. Sparrius ${ }^{1 *}$, Anders Tehler ${ }^{2}$ \& Klaus Kalb 3
}

\section{Article info}

Received: 6 Oct. 2019

Revision received: 14 Nov. 2019

Accepted: 14 Nov. 2019

Published: 2 Jun. 2020

\section{Associate Editor}

Damien Ertz

\begin{abstract}
A new species of Enterographa (Arthoniales: Roccellaceae) is described. E. kinabaluensis from Kota Kinabalu is characterized by the presence of punctiform soralia and norstictic acid. The saxicolous Fulvophyton serusiauxii is described from coastal Mexico and differs from the corticolous $F$. klementii in having much smaller ascospores.
\end{abstract}

Key words: taxonomy, Roccellaceae, Opegraphaceae, Roccellographaceae, Arthoniales

\section{Introduction}

The genus Enterographa (Arthoniales: Roccellaceae) was monographed by Sparrius (2004) and now contains 68 species in its current circumscription with additional taxa described in the genus (Sparrius 2004; Sparrius et al. 2006; Aptroot et al. 2007, 2013; Cáceres 2007; Sparrius \& Aptroot 2007; Singh \& Pinokiyo 2008; Sparrius \& Björk 2008; Seaward \& Aptroot 2009; Yeshitela et al. 2009; Gao et al. 2009; Ertz 2009; Sipman 2011; Morse 2013; Seavey \& Seavey 2014; Ertz et al. 2014, 2015; Jagadeesh Ram 2016; McCarthy \& Elix 2016; van den Boom \& Sipman 2016; Weerakoon et al. 2016; Seavey et al. 2017; Cáceres \& Aptroot 2017; Etayo 2017; Aptroot \& Cáceres 2018; Van den Broeck \& Ertz 2018; Gupta et al. 2019). Enterographa remains polyphyletic, with two or three distinct groups (Ertz \& Tehler 2011; Aptroot \& Cáceres 2017). The first is Enterographa s.str., placed in the Roccellaceae which includes the type E. crassa. The second group belongs to the Opegraphaceae and contains at least $E$. anguinella (Ertz et al. 2009) and probably many other corticolous, saxicolous and lichenocolous species currently placed in Enterographa. Aptroot \& Cáceres (2017) placed E. anguinella in the genus Nyungwea; however, the affinity to this genus was based on a very limited number of taxa, and the relations between genera in the Opegraphaceae therefore differ slightly between studies (Ertz et al. 2009; Aptroot \& Cáceres 2017). A third

\footnotetext{
BLWG, Hollandse Toren 40, 3511 BN Utrecht, The Netherlands

${ }^{2}$ Naturhistoriska Riksmuseet, Enheten för Botanik, Box 50007, S-104 05 Stockholm, Sweden

${ }^{3}$ Lichenologisches Institut Neumarkt, Im Tal 12, D-92318 Neumarkt, Germany

*Corresponding author e-mail: sparrius@blwg.nl
}

group may comprise foliicolous species, which differ in having ellipsoid instead of clavate asci and a Phycopeltis photobiont, similar to the foliicolous Opegrapha species now placed in Fouragea (Frisch et al. 2014).

Enterographa subserialis and many other Sclerophyton species were transferred to Fulvophyton, which forms a strongly supported group. Fulvophyton is characterized by the usually white-pruinose, grouped punctiform ascomata, hyaline hypothecium and macrocephalic ascospores (Ertz \& Tehler 2011). In this paper we describe further species in both genera, following the current classification.

\section{Materials and methods}

Specimens were collected during collection trips by the second author in Mexico (2016) and by the third author in Kinabalu Park (2014). Microscopic characters were studied in tap water using an Olympus $\mathrm{BH} 2$ microscope at $1000 \times$. Thin-layer chromatography (TLC) was performed in solvent A (Orange et al. 2001). UV fluorescence was tested with a $365 \mathrm{~nm}$ LED source.

\section{Results}

Taxonomy

Enterographa kinabaluensis Sparrius \& Kalb, sp. nov.

(Fig. 1)

MycoBank MB 833322

Diagnosis: Enterographa with punctiform soralia, from which shortly lirelline ascomata arise. Ascospores 4-5 × 39-52 $\mu \mathrm{m}$, 11-17 septate. Thallus with norstictic acid. 
A

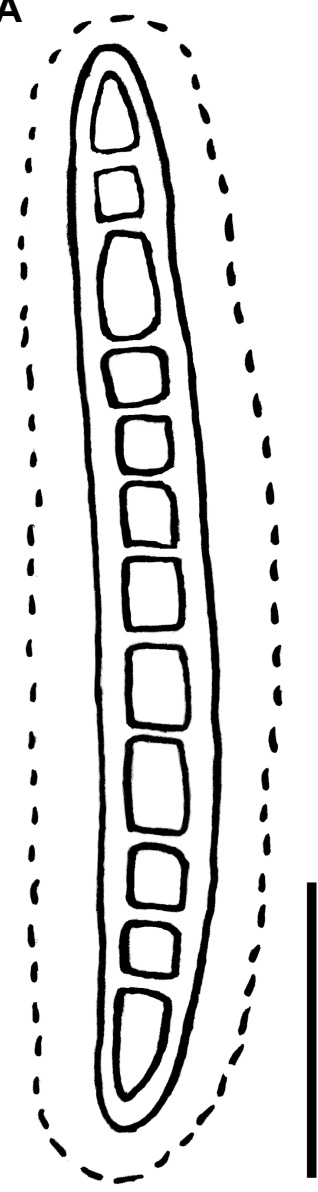

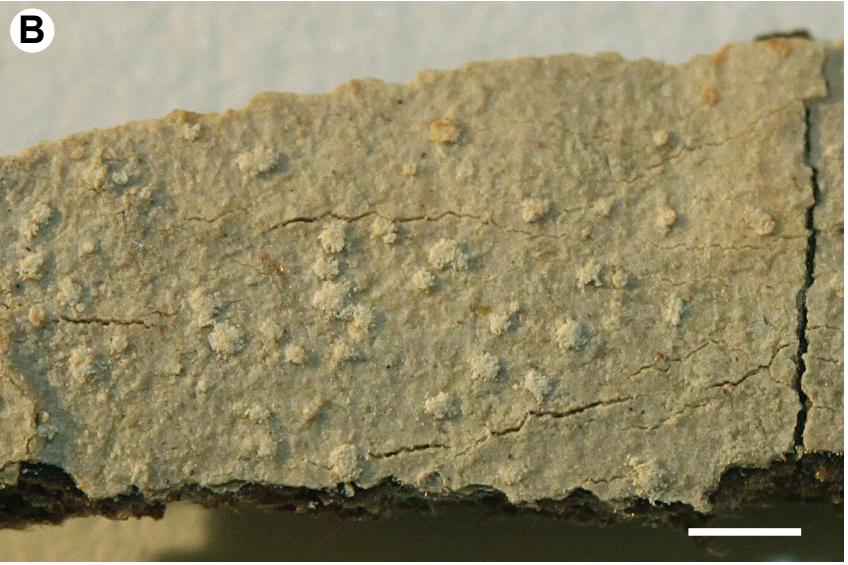

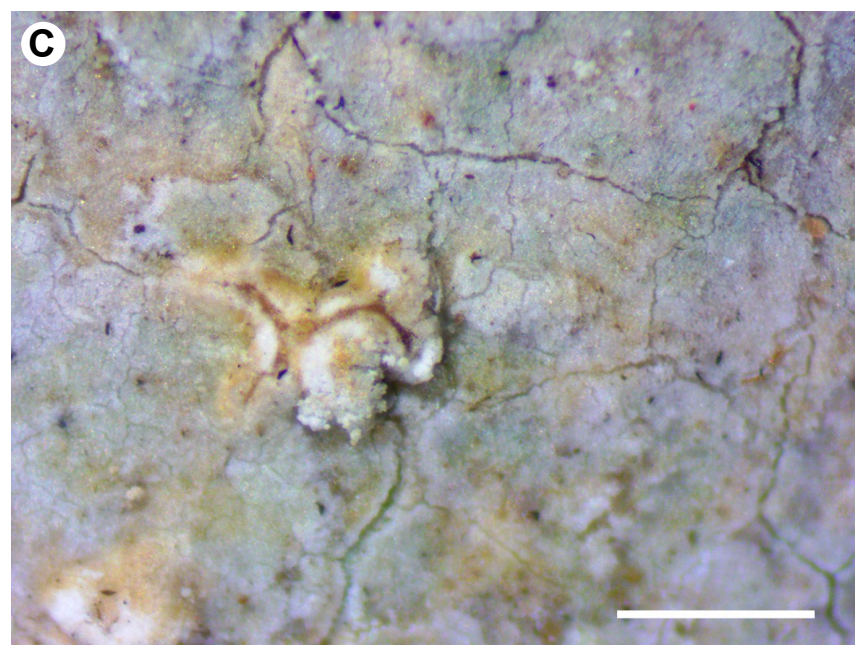

Figure 1. Enterographa kinabaluensis. A - ascospore; B - thallus showing punctiform soralia; C - ascoma arising from a soralium. Scales: $\mathrm{A}=10 \mu \mathrm{m} ; \mathrm{B}-\mathrm{C}=1 \mathrm{~mm}$.

Type: Malaysia, Borneo, Sabah, Kota Kinabalu, Sapi Island. Coastal rainforest, corticolous, $06^{\circ} 00^{\prime} 14^{\prime \prime} \mathrm{N}, 116^{\circ} 00^{\prime} 57^{\prime \prime} \mathrm{E}$, 30-50 m alt., 8 Aug. 2014, leg. K. Kalb \& A. Mertens 40346 (B - holotype; TLC!).

Description. Thallus smooth, continuous to finely areolate, white, water-absorbing, able to cover a large area of bark surface, thin, 100-150 $\mu \mathrm{m}$ tall. Photobiont trentepohlioid. Prothallus thin and black or absent. Upper algae-free medulla $\sim 10 \mu \mathrm{m}$ thick, of densely interwoven hyphae. Medulla cream-colored, with abundant crystals of norstictic acid (dissolving in $\mathrm{KOH}$ to form a yellow solution, rapidly followed by the formation of clusters of red needle-shaped crystals). Soralia punctiform, 0.3-0.7 mm diam. Soredia farinose, white. Ascomata shortly lirelline, sessile, often arising from soralia, disc pale orange-brown, $0.1-0.2 \times 0.1-0.4 \mathrm{~mm}$, aggregated in linear or stellate pseudostromata. Thalline margin indistinct, somewhat paler than thallus, $0.05 \mathrm{~mm}$ wide. Excipulum hyaline, very thin, $\sim 5 \mu \mathrm{m}$ wide. Hypothecium hyaline, $\sim 70 \mu \mathrm{m}$ tall. Hymenium hyaline, $\sim 100 \mu \mathrm{m}$ tall. Paraphysoids $\sim 1.0 \mu \mathrm{m}$ wide, tips widened to $1.5 \mu \mathrm{m}$, irregularly branched and anastomosing. Epithecium straw-colored, $\sim 20 \mu \mathrm{m}$ tall, $\mathrm{K}-$. Asci clavate, $\sim 70-100 \times 15 \mu \mathrm{m}, 8$-spored. Ascospores fusiform, hyaline, (9-)11(-17)-septate, 4-5 × 39-52 $\mu \mathrm{m}$, excluding perispore, perispore distinct, $1-3 \mu \mathrm{m}$ wide in K. Conidiomata not observed.
Chemistry. Thallus and ascomata $\mathrm{C}-, \mathrm{K}+$ yellow-red, PD+/- yellow, UV-; TLC: norstictic acid; amyloidy: asci and hymenium I-.

Distribution and ecology. Only known from the type locality in coastal rainforest. Corticolous.

Etymology. Named after the type locality near Kota Kinabalu.

Remarks. It is easily recognized when fertile by the white thallus with punctiform soralia, from which the ascomata arise. Other known Enterographa species with a sorediate thallus are E. zephyri, which has an entirely sorediate green thallus containing erythrin (Sparrius 2004), and E. incognita (Ertz et al. 2014), which is also entirely sorediate and contains roccellic acid. The presence of ascomata on the soredia might indicate a parasitic relation. However, we ruled this out because of the identical chemistry of both the thallus and ascomatal margin. The new species would key out as Enterographa sorediata in Seavey \& Seavey (2014), but that species is now synonymous with Syncesia myrticola (Ertz et al. 2018).

Fulvophyton serusiauxii Sparrius \& Tehler, sp. nov.

(Fig. 2)

MycoBank MB 833323 
A

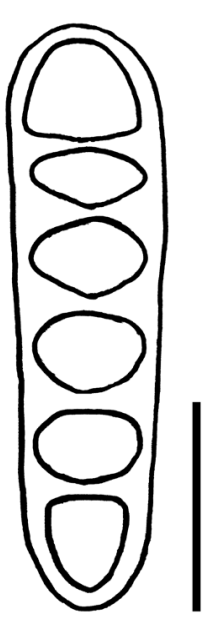

B
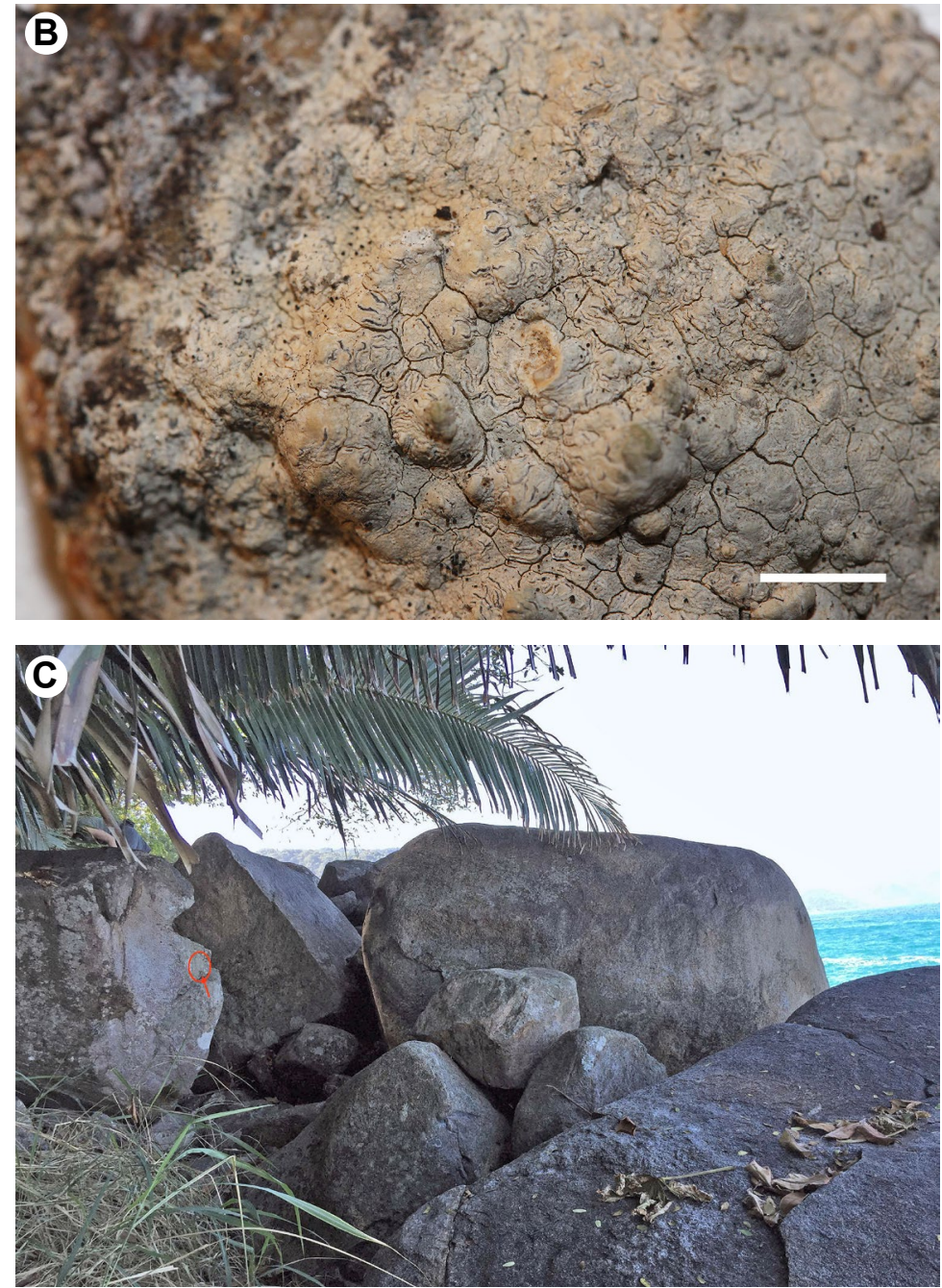

Figure 2. Fulvophyton serusiauxii. A - drawing of an ascospore. B - thallus. $\mathrm{C}-$ collecting locality. $\mathrm{Scales}: \mathrm{A}=10 \mu \mathrm{m}$; $\mathrm{B}=5 \mathrm{~mm}$.

Diagnosis: Saxicolous Fulvophyton with thick, cream-colored, areolate thallus. Ascomata lirelline. Ascospores 5-6 $\times 20-22 \mu \mathrm{m}$, 5-septate. Thallus with norstictic acid.

Type: Mexico, Estado de Jalisco, South of Puerto Vallarta along highway 200 north of Mismaloya just opposite to Los Arcos National Underwater Park, saxicolous on granitic boulders on the beach, $20^{\circ} 32^{\prime} 34^{\prime \prime} \mathrm{N}, 105^{\circ} 17^{\prime} 16^{\prime \prime} \mathrm{W}, 1 \mathrm{~m}$ alt., 7 Jan. 2016, leg. A. Tehler 10911 (S - holotype; TLC!).

Description. Thallus thick, areolate, cream-colored, matte, water-absorbing, 100-1000 $\mu$ m thick. Photobiont trentepohlioid. Prothallus black-brown. Upper algae-free medulla $\sim 50 \mu \mathrm{m}$ thick, of densely interwoven hyphae. Medulla cream-colored. Ascomata lirelline, immersed in areoles, disc black, partly white-pruinose, $0.15-0.2 \times$ $0.5-1.2 \mathrm{~mm}$, often branched, not notably aggregated in pseudostromata. Thalline margin indistinct, somewhat paler than thallus, $0.05 \mathrm{~mm}$ wide. Excipulum hyaline, very thin, $\sim 10 \mu \mathrm{m}$ wide. Hypothecium hyaline, $\sim 30 \mu \mathrm{m}$ tall. Hymenium hyaline, $\sim 100 \mu \mathrm{m}$ tall. Paraphysoids $\sim 1.0 \mu \mathrm{m}$ wide, tips widened to $1.5 \mu \mathrm{m}$, irregularly branched and anastomosing. Epithecium straw-colored, $\sim 15 \mu \mathrm{m}$ tall, $\mathrm{K}-$. Asci clavate, $\sim 70-100 \times 20 \mu \mathrm{m}, 8$-spored. Ascospores ellipsoid, hyaline, 5-septate, 20-22(-25) $\times 5-6 \mu \mathrm{m}$ excluding perispore, perispore indistinct in $\mathrm{K}$. Young ascospores with enlarged cells on both ends, as typical for this genus. Conidiomata not observed.

Chemistry. Thallus and ascomata $\mathrm{C}-, \mathrm{K}+$ yellow-red, PD+/- yellow, UV-; TLC: norstictic acid; amyloidy: asci and hymenium $\mathrm{I}+$ red.

Distribution and ecology. Only known from the type locality. Saxicolous on granite boulders on the Pacific Ocean shore. The tidal range along the coastline is very low, and contact with saltwater is probably limited to a few days in the hurricane season.

Etymology. The name is dedicated to Professor Emmanuël Sérusiaux on the occasion of his retirement from his position at the University of Liège.

Remarks. Very similar to the mainly corticolous Fulvophyton klementii, which has much larger ascospores $(30 \times 7.5 \mu \mathrm{m}$ on average), shorter, ellipsoid ascomata, and ascomata not notably aggregated in pseudostromata. The saxicolous Enterographa subgelatinosa is also similar in appearance but it has a faint $\mathrm{C}+$ red and $\mathrm{P}+$ yellow reaction. Fulvophyton calcicola is known from the Atlantic coast in Florida; it grows on calcareous rock and contains no secondary compounds. 


\section{Acknowledgements}

The authors thank André Aptroot for performing TLC on the sample from Mexico.

\section{References}

Aptroot, A. \& Cáceres, M. E. 2017. New Arthoniales from Amapá (Amazonian North Brazil) show unexpected relationships. The Lichenologist 49: 607-615.

Aptroot, A. \& Cáceres, M. E. 2018. New species and new records of lichens from inselbergs and surrounding Atlantic rain forest in the Chapada Diamantina (Bahia, Brazil). Herzogia 31: 359-373.

Aptroot, A., Saipunkaew, W., Sipman, H. J. M., Sparrius, L. B. \& Wolseley, P. A. 2007. New lichens from Thailand, mainly microlichens from Chiang Mai. Fungal Diversity 24: 75-134.

Aptroot, A., Ertz, D., De Lima, E. L., De Jesus, K. A., Maia, L. C. \& Cáceres, M. E. 2013. Two new species of Roccellaceae (Ascomycota: Arthoniales) from Brazil, with the description of the new genus Sergipea. The Lichenologist 45: 627-634.

Cáceres, M. E. 2007. Corticolous crustose and microfoliose lichens of northeastern Brazil. Libri Botanici 22: 1-168.

Cáceres, M. E. \& Aptroot, A. 2017. Lichens from the Brazilian Amazon, with special reference to the genus Astrothelium. The Bryologist 120: $166-182$.

Ertz, D. 2009. A new species of Enterographa, E. diederichiana (Roccellaceae), from Zambia. The Bryologist 112: 390-393.

Ertz, D. \& Tehler, A. 2011. The phylogeny of Arthoniales (Pezizomycotina) inferred from nucLSU and RPB2 sequences. Fungal Diversity 49: 47-71.

Ertz, D., Miadlikowska, J., Lutzoni, F., Dessein, S., Raspé, O., Vigneron, N., Hofstetter, V. \& Diederich, P. 2009. Towards a new classification of the Arthoniales (Ascomycota) based on a threegene phylogeny focussing on the genus Opegrapha. Mycological Research 113: 141-152.

Ertz, D., Tehler, A., Irestedt, M., Frisch, A., Thor, G. \& van den Boom, P. 2014. A large-scale phylogenetic revision of Roccellaceae (Arthoniales) reveals eight new genera. Fungal Diversity 70: 31-53.

Ertz, D., Flakus, A., Oset, M., Sipman, H. J. M. \& Kukwa, M. 2015. A first assessment of lichenized Arthoniales in Bolivia with descriptions of two new species. Phytotaxa 217: 1-25.

Ertz, D., Coppins, B. J. \& Sanderson, N. A. 2018. The British endemic Enterographa sorediata is the widespread Syncesia myrticola (Roccellaceae, Arthoniales). The Lichenologist 50: 153-160.

Etayo, J. 2017. Hongos liquenícolas de Ecuador. Opera lilloana 50: $1-535$

Frisch, A., Thor, G., Ertz, D. \& Grube, M. 2014. The arthonialean challenge: restructuring Arthoniaceae. Taxon 63: 727-744.

Gao, B., Li, J. \& Wei, J. C. 2009. A new foliicolous lichen, Enterographa hainanensis. Mycosystema 28: 175-177.
Gupta, P., Joseph, S. \& Sinha, G. P. 2019. Enterographa assamica, a new species from North-East India. Taiwania 64: 1-3.

Jagadeesh Ram, T. A. M. 2016. Additional new species in Roccellaceae s.1. from the Andaman and Nicobar Islands, India. Phytotaxa 246: 281-286.

Mccarthy, P. M. \& Elix, J. A. 2016. Five new lichen species (Ascomycota) from South-Eastern Australia. Telopea 19: 137-151.

Morse, C. A. 2013. A new lichenicolous Enterographa (Arthoniales, Roccellaceae) from Central North America. Opuscula Philolichenum 12: 233-240.

Orange, A., James, P. W. \& White, F. J. 2001. Microchemical methods for the identification of lichens. British Lichen Society, London.

Seavey, F. \& Seavey, J. 2014. New additions to the lichen genus Enterographa (Roccellaceae) from Everglades National Park including an updated world key. The Lichenologist 46: 83-93.

Seavey, F., Seavey, J., Gagnon, J., Guccion, J., Kaminsky, B., Pearson, J., Podaril, A. \& Randall, B. 2017. The Lichens of Dagny Johnson Key Largo Hammock Botanical State Park, Key Largo, Florida, USA. Florida Museum of Natural History Bulletin 53: 201-268.

Seaward, M. R. D. \& Aptroot, A. 2009. Checklist of lichens for the Seychelles Group. Bibliotheca Lichenologica 99: 335-366.

Singh, K. P. \& Pinokiyo, A. 2008. New taxa of foliicolous lichens from eastern India. The Lichenologist 40: 23-29.

Sipman, H. J. M. 2011. New and notable species of Enterographa, Niebla, and Sclerophyton s.lat. from coastal Chile. Bibliotheca lichenologica 106: 297-308.

Sparrius, L. B. 2004. A monograph of Enterographa and Sclerophyton. Bibliotheca Lichenologica 89: 1-141.

Sparrius, L. B. \& Aptroot, A. 2007. A new lichenicolous Enterographa species from Britanny (France). The Lichenologist 39: 315-317.

Sparrius, L. B. \& Björk, C. R. 2008. Enterographa oregonensis (Roccellaceae), a new foliicolous species from the Northwest coast of North America. The Bryologist 111: 487-489.

Sparrius, L. B., Saipunkaew, W., Wolseley, P. A. \& Aptroot, A. 2006. New species of Bactrospora, Enterographa, Graphidastra and Lecanographa from northern Thailand and Vietnam. The Lichenologist 38: 27-36.

Van den Boom, P. P. G. \& Sipman, H. J. M. 2016. Foliicolous lichens from Suriname and Guyana: New records and three new species. Folia Cryptogamica Estonica 53: 101-110.

Van den Broeck, D. \& Ertz, D. 2018. Enterographa confusa sp. nov. (Roccellaceae, Arthoniales) discovered by chance in type material of its host lichen Arthonia ochraceella, described more than a century ago. Phytotaxa 343: 89-93.

Weerakoon, G., Wolseley, P. A., Arachchige, O., Cáceres, M. E., Jayalal, U. \& Aptroot, A. 2016. Eight new lichen species and 88 new records from Sri Lanka. The Bryologist 119: 131-142.

Yeshitela, K., Fischer, E., Killmann, D. \& Sérusiaux, E. 2009. Two new foliicolous species of Enterographa (Roccellaceae) from Kenya. The Lichenologist 41: 17-23. 